\title{
THE DIVERSITY Of FRUIT FLIES IN RED GUAVA CROPS AND PARASITOID PARASITIZATION LEVEL IN DISTRICT DELI SERDANG
}

\author{
Putri Mustika Sari ${ }^{1 *}$, Darma Bakti², Maryani Cyccu Tobing ${ }^{2}$ \\ ${ }^{1}$ Post Graduate of Agrothechnology, Faculty of Agriculture, University of Sumatera Utara, Medan, Indonesia. \\ ${ }^{2}$ Agrothechnology Department, Faculty of Agriculture, University of Sumatera Utara, Medan, Indonesia. \\ *Corresponding Author: h0lm3s44@ymail.com
}

\begin{abstract}
Morphological and Molecular of Identification Bactrocera sp. (Diptera: Tephritidae) in 5 Location of Red Guava Crops District Deli Serdang. Fruit flies are a concern in the world because they are an important pest in fruits. Seven species of fruit flies (Bactrocera carambolae, Bactrocera papayae, Bactrocera curcubitae, Bactrocera caudata, Bactrocera albistrigata, Bactrocera tau, Bactrocera umbrosa) have been identified from the morphological identification of fruit flies in LIPI. The fruit fly is obtained from trapping with methyl eugenol, cocoa waste processing, and a mixture of both. Found 2 species of parasitoid (Psytallia sp. near Walker; Psytallia sp. near Walkeri) from the rearing of fruit that was attacked at five locations of red guava plantation district Deli Serdang.
\end{abstract}

Keywords : Bactrocera spp., morphology, atractant, parasitoid

\section{INTRODUCTION}

Fruit flies (Bactrocera sp.) are of concern in the world because they are an important pest in fruit, in Indonesia have experienced problems in fruits commodities (Suputa et al., 2007). Fruit farming can not be separated from pests, which can decrease production and become limiting factor of inter-country trade (Kardinan et al., 2009).

Red guava productivity in District Deli Serdang is reported to have decreased since 2010. Red Guava production of 35.261 dropped to 12.661 tons in 2014 (BPS, 2016). Reduced productivity of red guava one of them can be caused by pest attacks that cause damage to the fruit, and decrease the quality and quantity of the harvest (Amin, 2015).

That Bactrocera cucurbitae and B. papayae only attack papaya fruit only, while fruit flies that attack more than one fruit is $B$. carambolae attack mango fruit, starfruit, guava, guava water. $B$. albistrigata attack mango, guava, guava (Rahardjo et al., 2009). Various efforts to control fruit flies have been done among others by wrapping, sterile male insect technique, pesticide spraying, sanitation, and biological control (Dhillon et al ., 2005). One of the biological control that is by utilizing the role of parasitoid comes from family branconidae (Hymenoptera), namely Fopius sp. and Biosteres sp. which can suppress the population of fruit flies in the field (Siwi et al., 2006). Another fruit fly control that is effective and environmentally friendly is the use of trap atraktan (Kardinan et al., 2009). This study aims to identify the species that attack the red guava crops and parasitoid parasitation level in the district Deli Serdang

\section{MATERIAL AND METHOD}

\subsection{Collection of Fruit Flies}

Collection of fruit fly samples using modified Steiner traps and attracted attractants. Traps are made using yellow painted plastic containers, and inside are placed cotton for place of attractant. Administering of attractant to cotton with syringes in accordance with each treatment and repeating each sampling. Trap mounting is done at $07.00 \mathrm{WIB}$. Trap is fitted with zig zag diagonal slice method which is randomly determining where fruit fly trap in red guava crops in each sampling location, where the distance between traps $\pm 20 \mathrm{~m}$ adjusted with different spacing in each location. The number of traps to be installed in each sample location is 9 pieces and the total trap throughout the sample location is 45 traps. The trap is suspended on a shaded tree (canopy) at an altitude of $\pm 1-1.5 \mathrm{~m}$ above ground level. The collection of fruit flies was done as much as $8 \mathrm{x}$ with weekly intervals. Trapped fruit flies were collected, inserted in a small bottle containing $70 \%$ alcohol, and given sample number, treatment, location, date of taking. Then samples were taken to the LIPI laboratory to be identified.

\subsection{Intake of Infected Fruits}

Five fruits were attacked by purposive random sampling $4 \mathrm{x}$ with 2 weeks interval at each sample location. The collected fruit was inserted in plastic bag, labeled location, date of taking and taken to laboratory. The infected fruit was put into plastic container with sand media and covered with gauze. The fruit is observed after 7 days (6-10 day cycle of larvae), to get fruit fly pupa then sand diayaksetiapiapiap once for 14 days (pupa cycle 8-12 days). The 
collected fruit fly pupa is placed in another plastic container covered with gauze. Imago fruit flies and parasitoids that appeared appeared in the form of a solution of honey until the imago was three days old. Then turned off by being put in the refrigerator, for 5-10 minutes. Then collected in a bottle containing 70\% alcohol and identified.

\subsection{Morphological Identification}

Fruit flies and parasitoids that have been found are identified morphologically include caput, thorax, wings, abdomen, using a microscope and assisted with fruit fly identification books, namely: The Australian Handbook For The Identification Of Fruit Flies (Drew, 2016); Taxonomy And Bioecology Important Fruit Flies Bactrocera spp. In Indonesia (Siwi et al., 2006); Tephritid Flies (White, 1988), Hymenoptera Of The World An Identification Guide To Families(Goulet \& Huber, 1993), at the Biology Research Center Laboratory of the Indonesian Institute of Sciences (LIPI).

\section{RESULT AND DISCUSION}

\subsection{Number of Fruit Fly Populations in the Field}

The results of collecting fruit flies at 5 locations of red guava plants showed that there were differences in the number of fruit flies trapped by using some atraktan compounds. The difference can be seen in Figure 1.

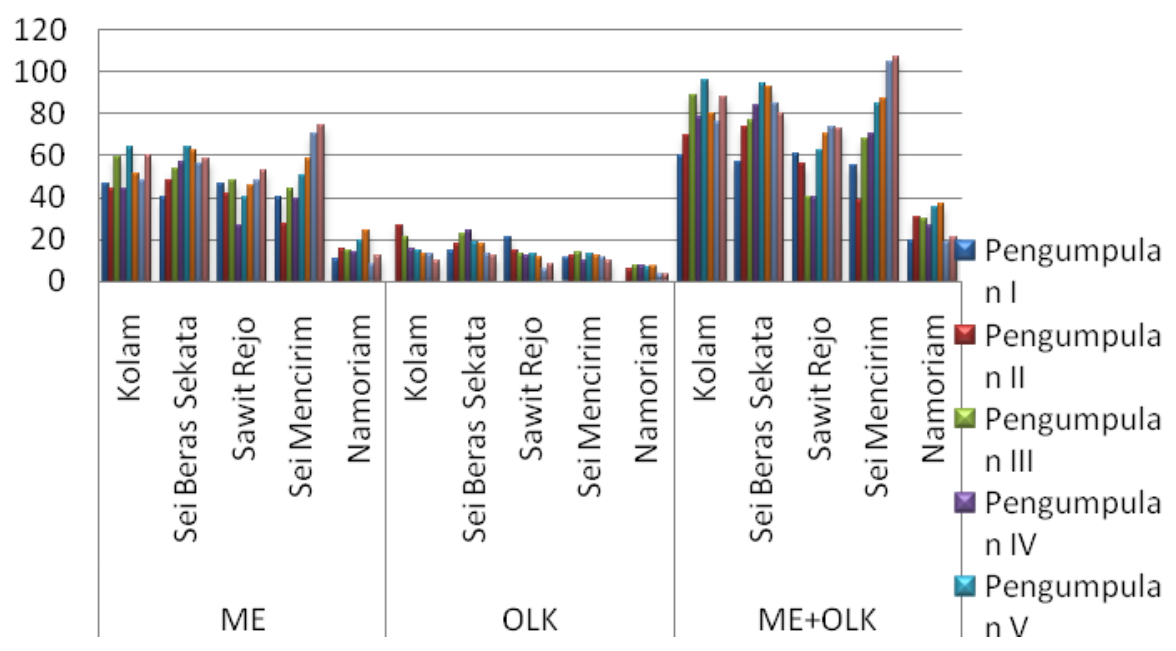

Figure 1. Graph of number of fruit flies interested in synthetic ME atraktan, OLK and ME + OLK at five locations of red guava crops of District Deli Serdang (Pengumpulan I toV means Collecting Process 1 to 5).

Based on the graph of the data in Figure 1, it shows that the average number of fruit flies trapped in the mixing treatment of the two atraktan compounds is more likely to attract male and female fruitflies. It is known that the specific ME attracted male fruit flies, because in the wild male fruit flies require ME for the formation of pheromones (Tan et al., 2011) whereas Fruit flies are not interested in ME, but are interested in hydrolyzate proteins present in the OLK for egg development and maturation of reproductive organs (Rahmawati, 2014). Specific synthetic ME attracts male fruit flies, but after mixed with processed cocoa waste (OLK) can attract fruit fly female (Indriyanti, 2012).

The result of the catch on the mixture of ME and OLK shows that the attractiveness of fruit flies is not only influenced by the mixture of the two atraktan compounds, but the abiotic and biotic factors also affect. At the planting site in the village of Sei Mencirim there are more trapped fruit flies than the other crops in the village. This occurs because of differences in the maintenance of crops, at the location of the plantation in the village Sei Mencirim in maintenance still use pesticides as the main component in the control of pest (peasumber of farmers, 2017). Known pesticides are not only toxic to target pest insects but also harmful to other living components (eg natural enemies), insect pests can be resistant, and in the long term the use of pesticides may increase the target pest population (Untung, 2006).

The behavior of fruit flies can be influenced by abiotic factors in the environment both temperature and humidity. It can be seen that Deli Serdang District in May to June has an average temperature of $26.7^{\circ} \mathrm{C}$ and an average humidity of $79.8 \%$. The average temperature and humidity contained in Deli Serdang district is very potential for the development of fruit fly life. Ginting (2009) says Fruit flies can grow at temperatures of $10-30^{\circ} \mathrm{C}$ and can grow well in $62-90 \%$ moisture. Fruit flours are active in the morning to noon and decrease in activity in the afternoon (Suputa et al., 2007). 
At 5 locations of red guava farming in Deli Serdang Regency, 7 species of fruit fly were associated with the planting, ie B. carambolae, B. papayae, B. curcubitae, B. caudata, B. umbrosa, B. albistrigata, B. tau. The identified species of fruit flies can be seen in Table 1.

Table 2. Type of Identified Fruit Flies

\begin{tabular}{|c|c|c|c|}
\hline No. & Location & Species Fruit Flies & $\begin{array}{c}\text { Fruit Crops About Red Guava } \\
\text { Crops } \\
\end{array}$ \\
\hline 1. & Sawit Rejo & $\begin{array}{l}\text { Bactrocera carambolae } \\
\text { Bactrocera papayae } \\
\text { Bactrocera umbrosa } \\
\text { Bactrocera curcubitae } \\
\text { Bactrocera caudata } \\
\text { Bactrocera sp. }\end{array}$ & Guava Crystals, Papaya, Chili \\
\hline 2. & Sei Beras Sekata & $\begin{array}{l}\text { Bactrocera carambolae } \\
\text { Bactrocera papaya } \\
\text { Bactrocera umbrosa } \\
\text { Bactrocera curcubitae } \\
\text { Bactrocera caudate }\end{array}$ & Guava Crystals, Papaya \\
\hline 3. & Namoriam & $\begin{array}{l}\text { Bactrocera carambolae } \\
\text { Bactrocera papaya } \\
\text { Bactrocera umbrosa } \\
\text { Bactrocera curcubitae } \\
\text { Bactrocera caudate }\end{array}$ & $\begin{array}{l}\text { Star Fruit, Thongsamsi Water } \\
\text { Guava, Duku, Papaya }\end{array}$ \\
\hline 4. & Sei Mencirim & $\begin{array}{l}\text { Bactrocera carambolae } \\
\text { Bactrocera papayae } \\
\text { Bactrocera umbrosa } \\
\text { Bactrocera curcubitae } \\
\text { Bactrocera caudata }\end{array}$ & Guava Crystals, Lemon Orange \\
\hline 5. & Kolam & $\begin{array}{l}\text { Bactrocera carambolae } \\
\text { Bactrocera papayae } \\
\text { Bactrocera umbrosa } \\
\text { Bactrocera curcubitae } \\
\text { Bactrocera caudate } \\
\text { Bactrocera albistrigata } \\
\text { Bactrocera tau } \\
\text { Bactrocera kinabalu }\end{array}$ & $\begin{array}{l}\text { Jambu Honey Deli, Jambu } \\
\text { Jamaica, Water Guava } \\
\text { Thongsamsi, Jackfruit, Kuini, } \\
\text { watermelon }\end{array}$ \\
\hline
\end{tabular}

There are several types of fruit plants around the cultivation of red guava fruit that becomes the fruit fly fly ie guava honey deli, jambu water thongsamsi, guava crystal, papaya, chilli, lemon, duku, jackfruit, guava jamaika, kuini, and starfruit (Table 1). This has an effect on the number and type of trapped fruit flies, at varying cultivation sites, of which the population and type of fruit flies are more numerous, thus allowing the number and type of fruit flies trapped in more pond villages than in other villages. Siwi et al. (2006) stated that the diversity of fruit flies is strongly influenced by the availability of host plants and the preferences of fruit flies to its host. In an area the fruit fly will move if the food source has been reduced (Khaeruddin, 2015).

P. guajava (Guava) is known as the main host of various species of fruit fly (Siwi et al., 2006; Suputa et al., 2010; Leblanc et al., 2013; Drew, 2016). Differences in host ranges possessed by the fruit fly species are influenced by the color spectrum, the volatile chemical compounds released by host plants, the preferences and perceptions of fruit flies on the morphology, nutrition, distribution and quantity of host plants as well as interactions with other organisms and individuals (Binyameen, 2013). 
The result of rearing of the affected fruit was found 2 species of parasitoid that attacked the fruit flies in the red guava cultivation of Psyttalia sp.near walker and Psyttalia sp. near walkeri. Parasitoid parasitic level obtained from the rearing of fruits attacked in 5 locations of red guava crops, can be seen in Table 3.

Table 3. Parasitoid parasitic level

\begin{tabular}{clccc}
\hline No. & Villages of Infected Fruits & $\begin{array}{c}\text { Number of } \\
\text { Fruits Flies }\end{array}$ & $\begin{array}{c}\text { Number of } \\
\text { Parasitoid }\end{array}$ & $\begin{array}{c}\text { Parasitization } \\
\text { Level }\end{array}$ \\
\hline 1. & Desa Sawit Rejo & 43 & 0 & 0 \\
2. & Desa Sei Beras Sekata & 54 & 4 & $6.9 \%$ \\
3. & Desa Namoriam & 33 & 0 & 0 \\
4. & Desa Sei Mencirim & 62 & 0 & 0 \\
5. & Desa Kolam & 27 & 1 & $3.6 \%$ \\
\hline
\end{tabular}

In Table 3, the level of parasitoid parasitation in five locations of low red guava plantation was seen only in two locations found parasitoid resulting from rearing of the affected fruit, ie Sei Beras Sekata village had a parasitic level of $6.9 \%$, and $3.6 \%$ of Kolam. Based on the parasitization it can be assessed the ability of low natural enemies in regulating the balance of the population of fruit flies in the crop. The low level of parasitation is one of them allegedly due to the adverse effects of insecticide treatment and uncooperative cultivation methods that adversely affect the presence of parasitoids in the crop. According to Astriyani (2014), the factors that influence the development of parasitoid one of them is the availability of appropriate feed, and the action of unwise use of pesticides. Parasitoid populations are also affected by plant age and host availability in the field (Herlinda, 2007).

\section{CONCLUSION}

Attractant compounds containing synthetic ME mixtures and OLK can increase the interest of male and female fruit flies in the field. The morphological identification of fruit flies on red guava cultivation in district Deli Serdang was found seven species, namely B. umbrosa, B. curcubitae, B. caudata, B. carambolae, B. papayae, B. tau, B. albistrigata. Two species of parasitoids were found that attacked the fruit fly in the red guava of Deli Serdang Regency, namely Psyttalia sp. near walker and Psyttalia sp. near walker, with the highest parasitoid parasit level of $6.9 \%$ found in Sei Beras Sekata Village.

\section{REFERENCES}

[BPS] Badan Pusat Statistik. 2016. Produksi tanaman buah-buahan di kabupaten Deli Serdang [Internet]. Tersedia pada: http://www.bps.go.id.

Amin, N. N. A., 2015. Perilaku oviposisi lalat buah Bactrocera papaya Drew \& hancock dan B. carambolae drew \& hancock Pada tingkat kematangan buah jambu biji (Psidium guajava L.). Tesis. IPB, Bogor.

Astriyani, N.K.N.K. 2014. Keragaman dan dinamika populasi lalat buah (diptera: tephritidae) yang menyerang tanaman buah-buahan di Bali. Tesis. Bioteknologi Pertanian. Universitas Udayana, Bali.

Binyameen, M. 2013. Olfactory mechanisms of host selection in phytophagous insects, Behavior, Neuron, and Receptor. Disertasi. Alnarp (SE): Swedish University of Agricultural Sciences.

Dhillon, M. K., R. Singh, J. S. Naresh, \& H. C. Sharma. 2005. The Melon Fruit Fly, Bactrocera cucurbitae: A Review of Its Biology and Management. Jurnal Insect Sci. 5:1-16.

Drew, D. 2016. The Australia handbook for the identification of fruit flies version 2.1. International Centre for Management of Pest Fruit Flies. Griffith University. Plant health Australia.

Ginting, R. 2009. Keanekaragaman Lalat Buah (Diptera: Tephritidae) di Jakarta, Depok, dan Bogor Sebagai Bahan Kajian Penyusunan Analisis Risiko Hama. Tesis. Institut Pertanian Bogor, Bogor.

Herlinda, S., Mayasari R., Adam T., \& Pujiastuti Y. 2007. Populasi dan serangan lalat buah Bactrocera dorsalis (Hendel) (Diptera: Tephritidae) serta potensi parasitoid pada pertanaman cabai (Capsicum annuum L.). Seminar Nasional dan Kongres Ilmu Pengetahuan Wilayah Barat. (ID). hlm:1-13.

Indriyanti, D.R., Subekti N., \& Latifah. 2012. Ketertarikan lalat buah Bactrocera pada ekstrak olahan limbah kakao berpengawet. Biosaintifika. 4: 83-88.

Khaeruddin. 2015. Identifikasi Lalat Buah Di Beberapa Kabupaten Di Provinsi Sulawesi Barat. Tesis. IPB, Bogor.

Leblanc L, Vueti E, Allwood A. 2013. Host Plant Records for Fruit Flies (Diptera: Tephritidae: Dacini) in the Pacific Islands: 2. Infestation Statistics on Economic Hosts. Proc Hawaii Entomol Soc. 45(1):83-117.

Rahmawati, Y.P. 2014. Ketertarikan Lalat Buah Bactrocera sp. Pada Senyawa Atraktan Yang Mengandung Campuran Protein dan Metil Eugenol. Skripsi, UNNES. Semarang.

Siwi, S.S., Hidayat P., \& Suputa. 2006. Taksonomi dan Bioekologi Lalat Buah Penting di Indonesia. Bogor: Kerjasama Balai Besar Penelitian dan Pengembangan Bioteknologi dan Sumberdaya Genetik Pertanian dengan Departement of Agriculture, Fisheries and Forestry AustraliaSuputa, E. Martono, Z. Hussein, \& A.T. 
Arminudin 2007. Preliminary study: Odontoponera denticulate as a potential predator to reduce true fruit fly population in Jogjakarta. Jurnal Ilmu-Ilmu Pertanian. 3(3): 351-356.

Suputa, E. Martono, Z. Hussein, \& A.T. Arminudin 2007. Preliminary study: Odontoponera denticulate as a potential predator to reduce true fruit fly population in Jogjakarta. Jurnal Ilmu-Ilmu Pertanian. 3(3): 351-356.

Suputa, Trisyono Y, Martono E, Siwi SS. 2010. Pembaruan informasi kisaran inang spesies lalat buah di Indonesia. Jurnal Perlintan. 16(2):62-75.

Tan, Tokushima I., Ono H., \& Nishida R. 2011. Comparison of phenylpropanoid volatiles in male rectal pheromone gland after methyl eugenol consumption, and molecular phylogenetic relationship of four global pest fruit fly species: Bactrocera invadens, B. dorsalis, B. correcta and B. zonata. Journal Chemical Ecology. 6 : 11611172.

Untung, K. 2006. Pengantar Pengelolaan Hama Terpadu. Edisi Kedua. UGM Press, Yogyakarta. 